\title{
Ammonium and phosphate removal using batch laboratory cultures by microalgae and cyanobacteria isolated from Costa Rica water bodies
}

\author{
Manuel Campos-Rudin ${ }^{1,2} \&$ Ana Margarita Silva-Benavides ${ }^{* 1,2}$ \\ 1. Escuela de Biología, Universidad de Costa Rica, San Pedro, San José 2060, Costa Rica; manuel.campos@ucr.ac.cr, \\ ana.silva@ucr.ac.cr \\ 2. Centro de Investigación en Ciencias del Mar y Limnología (CIMAR), Ciudad de la Investigación, Universidad de \\ Costa Rica, San Pedro, San José 2060, Costa Rica. \\ * Correspondence
}

Received 10-I-2017. Corrected 24-V-2017. Accepted 03-I-2018.

\begin{abstract}
This research analyzed three green microalgae (Scenedesmus sp., Chlamydomonas sp., and Chlorella sp.) and two cyanobacteria (Synechocystis sp. as unicellular strain and Nostoc sp. as filamentous strain) native from Costa Rica to remove high concentrations of ammonium and phosphate. Cultures were exposed for 120 $\mathrm{h}$ to initial concentrations of $70 \mathrm{mgL}^{-1}$ ammonium and $9 \mathrm{mgL}^{-1}$ phosphate, under constant light intensity of 60 $\mu \mathrm{mol} \mathrm{m} \mathrm{m}^{-2}$. Chlorella sp. showed the highest growth rate, followed by Chlamydomonas sp. and the cyanobacteria Nostoc sp. In contrast, Scenedesmus sp. and Synechocystis sp. cultures grew less than the other ones. The highest percentage of ammonium removal was achieved with Chlorella sp. followed by Chlamydomonas sp. and Synechocystis sp., then Scenedesmus sp. and Nostoc sp. Microalgae removed totally the initial phosphate concentration within $72 \mathrm{~h}$, while cyanobacteria Synechocystis sp. and Nostoc sp. removed phosphate partially. These microorganisms are promising for wastewater reclamation. Rev. Biol. Trop. 66(Suppl. 1): S83-S91. Epub 2018 April 01.
\end{abstract}

Key words: microalgae, cyanobacteria, ammonium, phosphorus, growth, productivity, wastewater.

The use of green microalgae in tertiary wastewater treatment was first proposed in the 1980s (Oswald, 1989). This technology is still rather limited, mainly because of the space it requires on land and the need for warm climatic conditions. Microalgae wastewater treatment systems are influenced by two major factors: 1) an adequate mixing of the culture suspension to ensure sufficient light to the cells, and 2) harvesting the microscopic cells from the treated water efficiently in order to complete the process (Benemann, Kooman, Weissman, \& Eisenberg, 1980; Benemann, 1989; Oswald, 1989, Acién, Gómez-Serrano, Morales-Amaral, Fernández-Sevilla, \& Molina-Grima, 2016). Several studies have been dedicated to the use of the microalgae for tertiary wastewater treatments, including species of Chlorella sp. (Tam \& Wong, 1996; de-Bashan \& Bashan, 2004;
Aslan \& Karapinar, 2006) and Scenedesmus sp. (González, Cañizares, \& Baena, 1997; Voltolina, Cordero, Nieves, \& Soto, 1999; Martínez, Sánchez, Jiménez, Yousfi, \& Muñoz, 2000; Voltolina, Gomez-Villa, \& Correa, 2005). Cyanobacteria, free or immobilized in a matrix, have also been investigated (De la Noüe, Lessard, \& Proulx, 1993; Chevalier, Proulx, Lessard, Vincent, \& de la Noüe, 2000; Olguín, Galicia, Mercado, \& Pérez, 2003). Other potential use of the green microalgae, it is related with the biomass generated by bioremediation procedures, which can be coupled to biotechnological applications like biogas, biofuel or biofertilizers production (Ansari, Hussain, Nawar, Qayyum, \& Ali, 2017; Diniz, Silva, Araújo, \& Chaloub, 2017).

Microalgae and cyanobacteria require nitrogen $(N)$ and phosphorus $(P)$ to synthesize 
nucleotides, amino acids, lipids, and carbohydrates (Dyhrman, 2016). These molecules are needed in energy transfer during metabolic reactions. $N$ can be found in compounds like ammonium $\left(\mathrm{NH}_{4}^{+}\right)$or nitrate $\left(\mathrm{NO}_{3}^{-}\right)$and $P$ can be found in phosphates $\left(\mathrm{PO}_{4}^{-3}\right)$ (Glass, Wolfe-Simon, \& Anbar, 2009). Microorganisms and plants regularly used $\mathrm{NO}_{3}^{-}, \mathrm{NH}_{4}^{+}$ and $\mathrm{PO}_{4}^{-3}$ in soils, fresh and oceanic water for many processes. However, high concentrations of $N$ and $P$ can promote water eutrophication which represents a serious ecological problem. Nutrient enrichment has generated blooms of some species of microorganisms like bacteria, cyanobacteria and microalgae, which release toxic compounds that impact ecosystems and biodiversity. High concentrations of $\mathrm{NH}_{4}^{+}$and $\mathrm{PO}_{4}^{-3}$ in water bodies can be generated by human activities, like domestic waste waters, the intensive use of fertilizers and agro industrial activities (Cai, Park, \& Yebo, 2013). In Costa Rica, the main sources of water contamination are organic compounds, fertilizers and industrial sources which produce a high input of $\mathrm{NH}_{4}^{+}$and $\mathrm{PO}_{4}^{-3}$ in rivers and marine waters (Hidalgo, 2012).

In this work, we present data on the removal capacity of $\mathrm{NH}_{4}-\mathrm{N}$ and $\mathrm{PO}_{4}{ }^{-3}-\mathrm{P}$, the growth rates and productivity of three microalgae (Chlorella sp., Scenedesmus sp. and Chlamydomonas sp.) and two types of cyanobacteria, the unicellular type as Synechocystis $\mathrm{sp}$. and the filamentous type as Nostoc sp. isolated from Costa Rican water bodies.

\section{MATERIALS AND METHODS}

\section{Organisms and culture conditions:}

The organisms studied were native strains of microalgae (Scenedesmus sp., Chlorella sp. and Chlamydomonas sp.) and cyanobacteria (Nostoc sp. and Synechocystis sp.) isolated from different waters bodies of Costa Rica. Scenedesmus sp., Chlorella sp. and Synechocystis sp. were isolated from a small polluted creek in Río Azul, San José. Chlamydomonas sp. was found in a secondary treatment oxidation pond operated by the Instituto Costarricense de Acueductos y Alcantarillados in Liberia, Guanacaste. The cyanobacteria Nostoc sp. was isolated from a lagoon in Monteverde, Puntarenas. Cells were maintained in laboratory conditions in $\mathrm{BG}_{11}$ medium (Rippka, 1988) in glass columns with a $400 \mathrm{ml}$ nutritive medium, at $28^{\circ} \mathrm{C}$, bubbled with a mixture of air/ $\mathrm{CO}_{2}(97: 3, \mathrm{v} / \mathrm{v})$ and illuminated with cool white fluorescent light at $60 \mu \mathrm{mol}$ photons $\mathrm{m}^{-2} \mathrm{~s}^{-1}$ measured on the surfaces of the cultures.

The culture medium was a synthetic medium (SM), enriched with $\mathrm{NH}_{4} \mathrm{Cl}$ and $\mathrm{K}_{2} \mathrm{HPO}_{4}$ to adjust the concentration of $\mathrm{NH}_{4}-\mathrm{N}$ and $\mathrm{PO}_{4}^{-3}-\mathrm{P}$ to the same level found in Río Azul. The average initial concentrations of $\mathrm{NH}_{4}-\mathrm{N}$ and $\mathrm{PO}_{4}^{-3}-\mathrm{P}$ in the starting cultures were $70 \mathrm{mgL}^{-1}$ and $9 \mathrm{mgL}^{-1}$, respectively. The $\mathrm{pH}$ of the medium was adjusted to 7.0 before sterilization.

Experimental design: For the experimental set up, cells in the log phase were harvested by means of centrifugation (Beckman Coulter, model Avanti J-26 XP Centrifuge, Brea, CA, USA) and re-suspended in filtered sterile distillate water (three times) to eliminate any traces of $\mathrm{BG}_{11}$ nutrients.

The experiments were carried out in duplicate $350 \mathrm{~mL}$ culture samples in $500 \mathrm{~mL}$ Erlenmeyer flasks. The initial dry weight was 200 $\mathrm{mgL}^{-1}$. Cultures were incubated at a temperature ranging from $24-26{ }^{\circ} \mathrm{C}$ in an orbital incubator (New Brunswick Scientific, USA), under $60 \mu \mathrm{mol}$ photons $\mathrm{m}^{-2} \mathrm{~s}^{-1}$ measured on the surface of the cultures with a flat quantum sensor Hansatech model SKP 200. All experiments were carried out under continuous illumination, with constant shaking of 75 RPM and supply of air/ $\mathrm{CO}_{2}$ ratio $97 / 3, \mathrm{v} / \mathrm{v}$. The starting $\mathrm{pH}$ of the cultures was 7.0; it was controlled daily and adjusted to the initial value by adding a diluted solution of $\mathrm{HCl}$. The constant supply of $\mathrm{CO}_{2}$ and the daily adjustment of the $\mathrm{pH}$ to 7 avoid the $\mathrm{PO}_{4}{ }^{-3}$ precipitation and $\mathrm{NH}_{4}-\mathrm{N}$ degassing as ammonia $\left(\mathrm{NH}_{3}\right)$ at high $\mathrm{pH}$. Controls (three replicates) without algal cells were maintained under the same conditions. 
Collected data: From each treatment, 10 $\mathrm{mL}$ of culture were sampled at $24 \mathrm{~h}$ intervals to measure $\mathrm{NH}_{4}-\mathrm{N}$ and $\mathrm{PO}_{4}^{-3}-\mathrm{P}$ concentrations and culture dry weight. The controls where evaluated daily to detect any loss of $\mathrm{NH}_{4}-\mathrm{N}$ by outgassing or $\mathrm{PO}_{4}{ }^{-3}-\mathrm{P}$ by precipitation. Cell dry weight determination was carried out on triplicate $5 \mathrm{~mL}$ samples. Each sample was filtered through a $0.45 \mu \mathrm{m}$ pore size pre-weighted glass fiber filters (Whatman, Maidstone, UK) and then dried at $100{ }^{\circ} \mathrm{C}$ for two hours. $\mathrm{PO}_{4}^{-3}-\mathrm{P}$ and $\mathrm{NH}_{4}-\mathrm{N}$ concentrations $\left(\mathrm{mgL}^{-1}\right)$ were determined by using a Photometer (Hanna Instruments: Multiparameter Bench Photometer for Laboratories model HI3200), in accordance with the Standard Methods for the Examination of Water and Wastewater (APHA, 1992). Samples were centrifuged at $6.000 \mathrm{xg}$ for five minutes to separate the algal cells, and care was used to avoid any loss of gaseous ammonia during experiments.

The mean productivity of each batch run, $\mathrm{Q}_{\mathrm{x}}\left(\mathrm{mg} \mathrm{L}^{-1}\right.$ day $\left.^{-1}\right)$, was calculated as: $\left(\mathrm{X}_{1}-\mathrm{X}_{0}\right) /$ $t_{1}-t_{0}$ where $\mathrm{X}_{1}\left(\mathrm{mgL}^{-1}\right)$ is the dry weight measured at the time $t_{l}$ (day), and $\mathrm{X}_{0} \mathrm{mgL}^{-1}$ is the dry weight at time $t_{0}$ (day).

The total amount of $\mathrm{NH}_{4}-\mathrm{N}$ removal during the experiment, $Q_{N}\left(\mathrm{mgL}^{-1}\right)$, was calculated as:

$$
\mathrm{Q}_{\mathrm{N}}=N_{o}-N_{m},
$$

where $N_{o}\left(\mathrm{mgL}^{-1}\right)$ is the initial $\mathrm{NH}_{4}-\mathrm{N}$ concentration and $N_{m}\left(\mathrm{mgL}^{-1}\right)$ is the $\mathrm{NH}_{4}-\mathrm{N}$ concentration remaining in the medium at the end of the experiment.

The total amount of $\mathrm{PO}_{4}{ }^{3-}-\mathrm{P}$ removal during the experiment $\left(\mathrm{mgL}^{-1}\right)$ was calculated as: $\mathrm{Q}_{\mathrm{P}}=P_{o}-P_{m}$, where $P_{o}\left(\mathrm{mgL}^{-1}\right)$ is the initial $\mathrm{PO}_{4}^{-3}-\mathrm{P}$ concentration and $P_{m}\left(\mathrm{mgL}^{-1}\right)$ is the $\mathrm{PO}_{4}^{-3}-\mathrm{P}$ concentration remaining in the medium at the end of the experiment.

Statistical analysis: The variables were examined using an analysis of variance (ANOVA) with a significance level of $\mathrm{p}<$ 0.05 . All the analyses were done in IBM SPSS statistics program v. 21.

\section{RESULTS}

Growth rate and culture productivity: Calculation of growth rate over time indicated that no lag phase took place, with the first phase being exponential growth $(\mu)$ within $24 \mathrm{~h}$, where all the studied strains showed a maximum growth rate $(\mu)$ (Fig. 1). Thereafter, growth rate remained constant followed by a decline at $72 \mathrm{~h}$, except for Chlorella sp. which dropped drastically after $24 \mathrm{~h}$. This strain showed higher growth rate compared to the other cultures $\left(\mu=0.0296 \mathrm{~h}^{-1}\right)$, while the cyanobacterium Synechocystis sp. had the lowest growth rate $\left(\mu=0.0039 \mathrm{~h}^{-1}\right)$. Significant differences in growth rates occurred between microalgae and cyanobacteria $(\mathrm{p}<0.05)$ (Fig. 1). Among the microalgae, Chlorella sp. showed the highest average productivity (178.16 mg $\mathrm{L}^{-1} \mathrm{~d}^{-1}$ ) and among cyanobacteria, Nostoc $\mathrm{sp}$. productivity was higher $\left(85.8 \mathrm{mg} \mathrm{L}^{-1} \mathrm{~d}^{-1}\right)$ compared to that attained with Synechocystis sp. (34.56 $\mathrm{mg} \mathrm{L}^{-1} \mathrm{~d}^{-1}$ ) (Fig. 2).

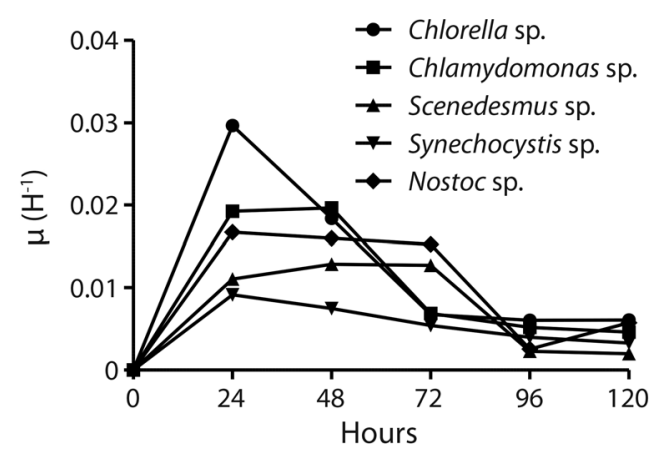

Fig. 1. Specific growth rate versus time (h) recorded in cultures of microalgae and cyanobacteria grown artificial medium.

Nitrogen Removal: Nitrogen removal varied among the strains $(\mathrm{p}<0.001)$ (Fig. 3a), except between the microalgae Scenedesmus sp. and the cyanobacteria Nostoc sp. where removal was similar $(\mathrm{p}>0.05)$ (Table 1). After $24 \mathrm{~h}$ of culture, a decrease in its concentration was observed in all the strains (between $5 \%$ and $25 \%$ of the initial $\mathrm{NH}_{4}-\mathrm{N}$ concentration). Chlorella sp. strain reduced the initial $\mathrm{NH}_{4}-\mathrm{N}$ 


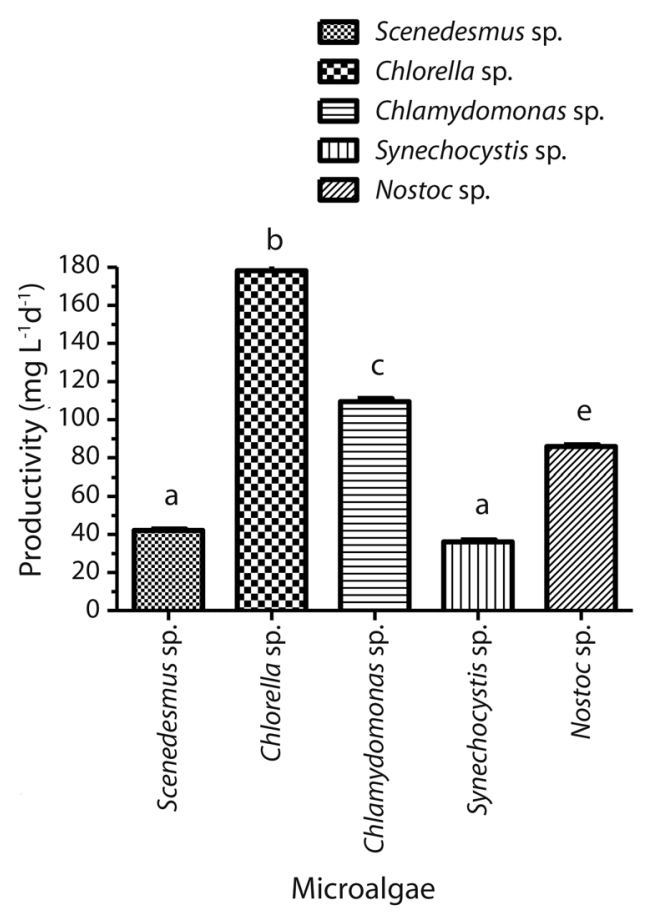

Fig. 2. Mean productivity $\left(\mathrm{mgL}^{-1} \mathrm{~d}^{-1}\right)$ of microalgae and cyanobacteria cultures. The values in the same column followed by different letters are significantly different ( $\mathrm{p}$ $<0.05)$. (*) a-a Synechocystis sp. and Scenedesmus sp. are not significantly different $(\mathrm{p}>0.05)$.

more than the half of the initial concentration within $48 \mathrm{~h}$ achieving almost a total removal of $\mathrm{NH}_{4}-\mathrm{N}$ at $120 \mathrm{~h}(92.25 \%)$. Among the other microalgae, Chlamydomonas sp. performed better than Scenedesmus sp. (37.5\% and $27 \%$ ) respectively, while Synechocystis sp. showed a little higher removal of $\mathrm{NH}_{4}-\mathrm{N}$ compared to Nostoc sp. (Table 1).

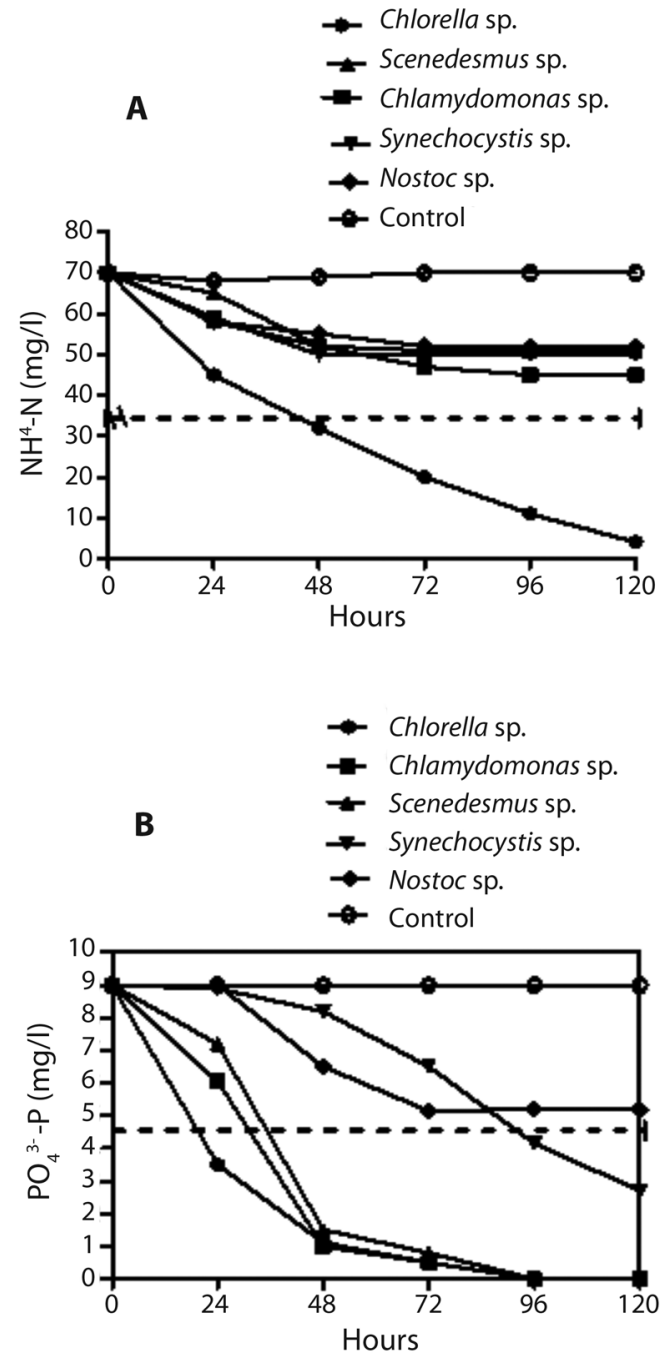

Fig. 3. NH4-N (a) and PO4-3-P (b) removal kinetics attained by the microalgae and cyanobacteria. Data were fitted with a one-phase exponential decay curve. Broken line indicates a $50 \%$ reduction in the initial ammonium and phosphate concentration.

TABLE 1

Total removal (\%) of $\mathrm{NH}_{4}-\mathrm{N}$ and $\mathrm{PO}_{4}^{-3}-\mathrm{P}$ after $120 \mathrm{~h}$ by microalgae and cyanobacteria

\begin{tabular}{lcc} 
& $\mathrm{NH}_{4}-\mathrm{N}$ removal $(\%)$ & $\mathrm{PO}_{4}^{-3}-\mathrm{P}$ removal $(\%)$ \\
Chlorella sp. & $92.25 *$ & 100 n.s. \\
Chlamydomonas sp. & $37.50 *$ & 100 n.s. \\
Scenedesmus sp. & 27.00 n.s. & 100 n.s \\
Synechocystis sp. & $29.75 *$ & $70.00 *$ \\
Nostoc sp. & 24.25 n.s. & $48.55 *$ \\
\hline
\end{tabular}

(n.s.) no significant differences. (*) Significantly different $(\mathrm{p}<0.001)$. 
Phosphorus removal: Microalgae removed $100 \%$ of the $\mathrm{PO}_{4}^{-3}-\mathrm{P}$ at the end of 120 $\mathrm{h}(\mathrm{p}>0.05)$, while cyanobacteria had the lowest percentages of removal $(p<0.001)$ (Table 1). The kinetics of $\mathrm{PO}_{4}^{-3}-\mathrm{P}$ removal was faster in all microalgae strains. There was a reduction of more than $50 \%$ after $24 \mathrm{~h}$ in Chlorella sp. and after $36 \mathrm{~h}$ in Scenedesmus sp. and Chlamydomonas sp., with complete $\mathrm{PO}_{4}^{-3}-\mathrm{P}$ removal within 96 h (Fig. 3b). The cyanobacteria Synechocystis $\mathrm{sp}$. showed a $50 \%$ reduction within $96 \mathrm{~h}$ but did not completely remove $\mathrm{PO}_{4}{ }^{-3}-\mathrm{P}$ $(70 \%)$ at the end of the experiment, Nostoc sp. showed the lowest $\mathrm{PO}_{4}{ }^{-3}-\mathrm{P}$ removal $(48.55 \%)$ (Fig. 3b).

\section{DISCUSSION}

Ideal candidate algal species for wastewater treatment should present the main following characteristics: 1) able to growth with high concentrations of inorganic nutrients, 2) efficiency to remove the pollutants, 3) high metabolic activity in order to cope with harsh environmental conditions, and 4) high growth rate. Microalgae strains tested in this work, showed better growth than the cyanobacteria one. An initial phase of log growth after $24 \mathrm{~h}$ in all the strains followed by a decreased of the biomass accompanied by a pronounced fall in the $\mathrm{PO}_{4}^{-3}-\mathrm{P}$ concentration, indicated that the growth was strongly affected by the presence of $\mathrm{PO}_{4}^{-3}-\mathrm{P}$ and $\mathrm{NH}_{4}-\mathrm{N}$ in the medium, especially $\mathrm{PO}_{4}^{-3}-\mathrm{P}$, suggesting that the consumption of this ion more than $\mathrm{NH}_{4}-\mathrm{N}$ by algae.

Culture growth depends on different factors such as light intensity, $\mathrm{pH}$, nutrients, carbon dioxide, mixing, and temperature. In wastewater, growth depends in part by the active nutrient uptake of the photosynthetic cells and their transformation into biomass (Voltolina et al., 2005). An excessive cell density could limit the light penetration into the water column and thus reduce the growth, particularly in scarcely mixed cultures.

The mixing of the culture is one of the most important requirements to obtain high productivities of the microalgal biomass (Abalde, Cid,
Fidalgo, Torres, \& Herrero, 1995); it allows to maintain a homogeneous distribution of nutrients to the cells, prevents sedimentation and allows a more uniform light distribution in the water column. In our experiments, the constant mixing of the cultures favored the productivity of Chlorella sp. and Chlamydomonas sp. strains. Kong, Li, Martínez, \& Ruan (2010) and Martínez et al., (2000) reported the agitation of the culture as one important factor in the growing of Chlamydomonas reinhardtii and Scenedesmus obliquus.

However, shaking in cyanobacteria cultures may have had a negative effect on the growth for example of Nostoc sp. This cyanobacterium has gas vacuoles for floating, favoring a better light incidence on the cell surface in absence of mixing. Shaking of the cultures, may represent an obstacle to buoyancy of Nostoc, reducing the possibility for it to capture the light and forsaking growth of cells. Similar findings have been reported by Silva-Benavides \& Torzillo (2012) in cultures of monoalgal Planktothrix. Visser, Ibelings, Van Der Veer, Koedood, \& Mur (1996), reported reduction in the growth of filamentous cyanobacteria as Aphanizomenon sp., in a lake in mixing conditions. Low $\mathrm{pH}$ in the water favored the growth of green algae and diatoms more than cyanobacteria (Shapiro, 1990; Visser et al., 1996). In our case, the $\mathrm{pH}$ of the cultures was close to 7.0, a condition that could have promoted the growth of algae more than cyanobacteria, which can to be more abundant in alkaline mediums.

Algal growth was accompanied by a decrease in $\mathrm{NH}_{4}-\mathrm{N}$ and $\mathrm{PO}_{4}^{-3}-\mathrm{P}$ concentrations in all the cultures, indicating that $N$ and $P$ removal could be mainly due to algal uptake and assimilation. The maintenance of $\mathrm{pH} 7$ during the experiments prevents the conversion of ammonium to ammonia gas which it happens at high $\mathrm{pH}$ and phosphate precipitation which it occurs at low pH (Nurdogan \& Oswald, 1995; Silva-Benavides \& Torzillo, 2012).

The uptake and assimilation rates of ammonium are higher than $\mathrm{NO}_{3}$ by primary producers because is less energetic demanding (Von Ruckert \& Giani, 2004; Escudero, 
Blanco, Lacalle, \& Pinto, 2014), and many genes involved in nitrate/nitrite assimilation are repressed in the presence of ammonium (Fernández, Llamas, \& Galván, 2008). The incorporation of ammonium into algal cells occurs through the action of the enzyme glutamine dehydrogenase and by transports of the AMT/MEP enzyme family (Raven \& Giordano, 2016), which has been demonstrated in Chlamydomonas sp. (Fernández, Llamas \& Galván, 2008; de Montaigu, Sanz- Luque, Macias, Galvan, \& Fernández, 2011).

The microalga Chlorella sp. showed a bioremoval capacity of almost $93 \%$ of the ammonium, which was considerably higher than what is reported in the literature (Tam \& Wong, 1996; Aslan \& Karapinar, 2006; Silva-Benavides \& Torzillo, 2012). The highest growth rate of this alga suggests that cells can recycle $N$ in proteins into the cells to maintain their growth. Aslan \& Karapinar (2006), pointed out that Chlorella vulgaris is able to remove around $50 \%$ of $\mathrm{NH}_{4}-\mathrm{N}$ when the concentration is between $41.8-92.8 \mathrm{mgL}^{-1}$ and the removing efficiency decreased at concentrations over $129 \mathrm{mgL}^{-1}$.

Similar trends have been reported in Chlamydomonas in high concentrations of $\mathrm{NH}_{4}-\mathrm{N}$, as the case of Chlamydomonas acidophila, which removed between 51.0 and $68.0 \mathrm{mgL}^{-1}$ of $\mathrm{NH}_{4}-\mathrm{N}$ with an initial concentration of 95 and $650 \mathrm{mgL}^{-1}$ in $240 \mathrm{~h}$ (Escudero et al., 2014). In our case, this alga showed a $37 \%$ removal of $\mathrm{NH}_{4}-\mathrm{N}$.

The microalgae Scenesdemus sp. can remove up to $100 \%$ ammonium when the concentration of this ion is below $40 \mathrm{mgL}^{-1}$ (González, Cañizares, \& Baena, 1997; Martínez et al., 2000; Voltolina et al., 2005), but concentrations higher than $100 \mathrm{mgL}^{-1}$ affect their removal capacity (Azov \& Goldman, 1982; Godos et al., 2010; Park, Jin, LIm, Park, \& Lee, 2010). In our study, the $\mathrm{NH}_{4}-\mathrm{N}$ concentration was $70 \mathrm{mgL}^{-1}$, which it could have affected the removal of this ion by this alga. The microalga Scenedesmus sp. can use both sources of nitrogen $\left(\mathrm{NO}_{3}\right.$ and $\left.\mathrm{NH}_{4}^{+}\right)$ without any preference (Park et al., 2010).
González-Garcinuño, Tabernero, SánchezAlvarez, del Valle, \& Galán (2014) showed that the best growing medium in autotrophic conditions for Scenedesmus abundans was based on $\mathrm{NH}_{4} \mathrm{NO}_{3}$, where the ammonium bioremoval increased if the solution has nitrate. This fact could explain the reduced removal of ammonium by this alga in our study, which the only source of $\mathrm{N}$ was from $\mathrm{NH}_{4} \mathrm{Cl}$.

Aslan \& Karapinar (2006), report that Chlorella sp. removes $\mathrm{PO}_{4}^{-3}$-P efficiently when its concentration is lower than $7.7 \mathrm{mgL}^{-1}$, which was similar in our experiment. Given the microalgae cultures exhausted the content in the medium within 48-96 h, we argued that $\mathrm{PO}_{4}^{-3}-\mathrm{P}$ limited the growth of cultures, principally for Chlorella sp. The growth stops drastically at $24 \mathrm{~h}$ of the experiment; it is supposed that the decreasing of $\mathrm{PO}_{4}^{-3}$-P from $24 \mathrm{~h}$ could severely reduce the growth rate of this microalga, contrary to Scenedesmus sp. and Chlamydomonas sp. which showed a linear growth during the time of $\mathrm{PO}_{4}^{-3}-\mathrm{P}$ reduction in the medium. The fast removal pattern of $\mathrm{PO}_{4}^{-3}-\mathrm{P}$ against $\mathrm{NH}_{4}-\mathrm{N}$ for all the three microalgae has also been reported by Lynch et al. (2015), who found 3.3 times faster phosphate removal against ammonium in Chlorella sp. and Scenedesmus sp. Our study demonstrated that Chlorella sp. and Chlamydomonas sp., the uptake of $\mathrm{NH}_{4}-\mathrm{N}$ and $\mathrm{PO}_{4}^{-3}-\mathrm{P}$ have contributed to the higher growth and productivity of these microalgae.

The cyanobacteria show less tolerance to high concentrations of $\mathrm{NH}_{4}^{+}$than microalgae (Glass et al., 2009; Collos \& Harrison, 2014). In cyanobacteria, ammonium is incorporated into carbon skeletons mainly through the glutamine synthetase-glutamate synthase cycle (Herrero, Muro-Pastor, \& Flores, 2001) and glutamate synthase (Muro-Pastor, Reyes, \& Florencio, 2005). In our study, both cyanobacteria did not show a good performance in the removal either $P$ or $N$. The majority of the enzymes used by cyanobacteria in $N$ assimilation required several metals as cofactors (Glass et al., 2009). The synthetic medium used in this study was not supplemented with metals, so it could reduce the capacity to uptake ammonium. 
Nostoc sp. is more sensitive to ammonium applications than others cyanobacterias in agricultural fields which induce a decrease of $\mathrm{pH}$ in the medium (Dai, Deblois, Liu, Jeneau \& Qui., 2008). We avoided this negative effect by keeping a neutral $\mathrm{pH}$. In reports with different sources of residual waste water, Nostoc muscurum showed a removal rate of $40-60$ $\%$ for $\mathrm{PO}_{4}^{-3}-\mathrm{P}$ and $20.9-96 \%$ for $\mathrm{NH}_{4}-\mathrm{N}$ (ElSheekh, El-Shouny, Osman, \& El-Gammal, 2014), similar to our findings. Concerning the assimilation of ammonium by phytoplankton species, cyanobacteria are better competitors than eukaryotic algae (Von Ruckert \& Giani, 2004). We would expect a higher removal capacity by Synechocystis sp. and Nostoc sp. against microalgae; however, we did not find this trend, suggesting that conditions other than $\mathrm{NH}_{4}-\mathrm{N}$ concentration could be influenced its uptake.

Nostoc sp., removed the lowest $\mathrm{NH}_{4}-\mathrm{N}$ or $\mathrm{PO}_{4}^{-3}-\mathrm{P}$ compared with all the strains studied, behaving like a low nutrient removal filamentous strain. This fact has been already observed by Seale, Boraas, \& Warren (1987) and Subramanian, Sumathi, \& Sivasubramanian (2009). These authors found that the uptake of $\mathrm{PO}_{4}^{-3}$ by Nostoc sp. was very low when sodium was not included in the medium solutions as in the present study.

The differences of removal of $\mathrm{PO}_{4}^{-3}-\mathrm{P}$ and $\mathrm{NH}_{4}-\mathrm{N}$ and the growth of the different microalga and cyanobacteria used in this experiment, suggest that the variations depend on the metabolic condition of the algae, the strain of algae and environmental conditions in the medium. The microalgae Chlorella sp. it is an excellent choice to pursue bioremediation of eutrophic waters with high input of $N$ and $P$. In terms of removal of $\mathrm{PO}_{4}^{-3}-\mathrm{P}$, all the algae, except Nostoc sp. showed an excellent performance compared to other studies (Aslan \& Karapinar, 2006). There are some possible strategies to improve bioremediation and growing performance, the use of different sources of $N$ in the medium (Gonzáles-Garcinuño et al., 2014; Lynch et al., 2015) or co-cultures microalgae and cianobacteria (Silva-Benavides \& Torzillo, 2012).
The use of these native cyanobacteria strains as filamentous Nostoc sp. and the unicellular Synechocystis sp., together with the green microalgae Chlorella sp., Scenedesmus sp. and Chlamydomonas sp., which are better acclimated to the specific environmental conditions of the country are good candidates to removed $\mathrm{N}$ and $\mathrm{P}$ compounds derived from urban o agricultural wastewater. The resulting biomass obtained from the bioremediation process, it can be used for different biotechnological applications, like biofertilizers or biofuels production, and these uses of the biomass can also give an economical input decrease the cost of waste water treatment procedures.

\section{ACKNOWLEDGMENTS}

This work was performed funds provided by the "Vicerrectoría de Investigación de la Universidad de Costa Rica", project number 808-B3-136. We thank Jenaro Acuña for his advice in chemical aspects. Jose Moncada gives the statistical support. Jimena Samper and Mario Espinoza for the review of the document. We also want recognize laboratory work of Dayana Vega, Diana Acuña, Andres Lee and Alejandra Solano.

\section{RESUMEN}

Remoción de amonio y fosfato en cultivos de laboratorio con microalgas y cianobacterias aisladas de cuerpos de agua de Costa Rica. La presente investigación utilizó las microalgas Scenedesmus sp,. Chlamydomonas sp. y Chlorella sp. y las cianobacterias Synechocystis sp. y Nostoc sp. nativas de Costa Rica, con el propósito de analizar la capacidad de remoción de amonio y fosfato. Las cepas se colocaron en medio de cultivo sintético, con concentraciones iniciales de amonio de $70 \mathrm{mgL}^{-1}$ y fosfato de $9 \mathrm{mgL}^{-1}$. El cultivo se realizó durante $120 \mathrm{~h}$, con luz constante a una intensidad de $60 \mu \mathrm{mol} \mathrm{m} \mathrm{m}^{-2} \mathrm{~s}^{-1}$. Se cuantificaron las siguientes variables cada $24 \mathrm{~h}$ en todos los cultivos: a) la tasa de crecimiento $(\mu)$, b) productividad $\left.\left(\mathrm{mgL}^{-1} \mathrm{~h}^{-1}\right), \mathrm{c}\right)$ concentración de amonio y fosfato. La microalga Chlorella sp. presentó la mayor tasa de crecimiento, luego Chlamydomonas sp. y la cianobacteria Nostoc sp. Los cultivos Scenedesmus sp. y Synechocystis sp. presentaron un menor crecimiento. La mayor remoción de nitrógeno se presentò en Chlorella sp., seguida por Chlamydomonas sp. y Synechosystis sp., Scenedesmus sp. y Nostoc sp. El fosfato se 
removió en forma total por las microalgas antes de las $72 \mathrm{~h}$, mientras que en Synechocystis sp. y Nostoc sp. fue removido parcialmente. El estudio indica potenciales aplicaciones especialmente de la microalga Chlorella sp. en la remoción de amonio y fosfato en aguas residuales urbanas.

Palabras clave: microalga, cianobacteria, nitrógeno, fósforo, crecimiento, productividad, agua residual.

\section{REFERENCES}

Abalde, J., Cid, A., Fidalgo, P., Torres, E., \& Herrero, C. (1995). Microalgas: cultivos y aplicaciones. La Coruña, Spain: Universidade Da Coruña.

Acién, F., Gómez-Serrano, C., Morales-Amaral, M., Fernández-Sevilla, J. \& Molina-Grima, E. (2016). Wastewater treatment using microalgae: how realistic a contribution might it be to significant urban wastewater treatment? Applied Microbiological Biotechnology, 100, 9013-9022.

Ansari, A., Hussain, A., Nawar, A., Qayyum, M. \& Ali, E. (2017). Wastewater treatment by local microalgae strains for $\mathrm{CO}_{2}$ sequestration and biofuel production. Applied Water Sciences, 7, 4151-4158. DOI 10.1007/ s1320-017-0574-9

APHA, AWWA, WPCF (1992). Standard methods for the examination of water and waste water (1995). Washington DC: American Public Health Association.

Aslan, S., \& Karapinar, I. (2006). Bacth kinetics of nitrogen and phosphorus removal from synthetic wastewater by algae. Ecological Engineering, 28, 64-70.

Azov, Y., \& Goldman, J. C. (1982). Free ammonia inhibition of algal photosynthesis in intensive culture. Applied Environmental Microbiology, 43, 735-739.

Benemann, J. (1989). The future of microalgal biotechnology. In R. Cresswell , T. Rees \& N. Shah (Eds.). Algal and cyanobacterial biotechnology (pp. 317337). England: Longman Scientific and Technical.

Benemann, J., Kooman, B., Weissman J., \& Eisenberg, D. (1980). Development of microalgal harvesting and high-rate pond technologies in California. In G. Shelef \& C. Soeder (Eds.). Algae Biomass: production and use (pp. 457-475). Amsterdam: Elsiever North Holland Biomedical Press.

Cai, T., Park, S., \& Yebo, L. (2013). Nutrient recovery from wastewater streams by microalgae. Renewable and Sustainable Energy Reviews, 19, 360-369.

Chevalier, P., Proulx, D., Lessard, P., Vincent, W., \& de la Noüe, J. (2000). Nitrogen and phosphorous removal by high latitude mat-forming cyanobacteria for potential use in tertiary wastewater treatment. Journal of Applied Phycology, 12, 105-112.
Collos, Y., \& Harrison, P. (2014). Acclimation and toxicity of high ammonium to unicellular algae. Marine Pollution Bulletin, 80, 8-29.

Dai, G., Deblois, Ch., Liu, S., Juneau, P., \& Qui, B. (2008). Differential sensitivity of five cyanobacterial strains to ammonium toxicity and its inhibitory mechanism on the photosynthesis of rice-field ciaynobacterium Ge-Xian-Mi (Nostoc). Aquatic Toxicology, 89, 113-121.

De la Noüe, J., Lessard, P., \& Proulx, D. (1993). Tertiary treatment of secondarily treated urban wastewater by intensive culture of Phormidium bohneri. Environmental Technology, 15, 449-458.

de Montaigu, A., Sanz Luque, E., Macias, M., Galvan, A., \& Fernández, E. (2011). Transcriptional regulation of $\mathrm{CDP} 1$ and CYG56 is required for proper $\mathrm{NH}_{4}$ sensing in Chlamydomonas. Journal of Experimental Botany, 62, 1425-1437.

de-Bashan, L., \& Bashan, Y. (2004). Recent advances in removing phosphorous from wastewater and its future use as fertiliser (1997-2003). Water Research, $38,4222-4246$.

Diniz, G., Silva, A., Araújo, O \& Chaloub, R (2017). The potential of microalgae biomass production for biotechnological purposes using wastewater resources. Journal of Applied Phycology, 29, 821-832.

Dyhrman, S. (2016). Nutrients and their acquisition: phosphorus physiology in microalgae. In M. A. Borowitzka, J. Beardall \& J. Raven (Eds.). The Physiology of Microalgae (pp. 155-178). Switzerland: Springer International Publishing Switzerland Press.

El-Sheekh, M., El-Shouny, W., Osman, M., \& El-Gammal, E. (2014). Treatment of sewage and industrial waste water effluent by the Cyanobacteria Nostoc muscorum and Anabaena subcylenderica. Journal of Water Chemistry and Technology, 36, 354-371.

Escudero, A., Blanco, F., Lacalle, A., \& Pinto, M. (2014). Ammonium removal from anaerobically treated effluent by Chlamydomonas acidophila. Bioresource Technology, 153, 62-68.

Fernández, E., Llamas, A., \& Galván, A. (2008). Nitrogen assimilation and its regulation. In D. Stern, E. Harris \& G. Witman (Eds.). The Chlamydomonas sourcebook (pp. 69-113). Amsterdam: Elsevier.

Glass, J., Wolfe-Simon, F., \& Anbar, A. (2009). Coevolution for metal availability and nitrogen assimilation in cyanobacteria and algae. Geobiology, 7, 100-123.

Godos, I., Vargas, V., Blanco, S., García, M., Soto, R., García-Encina, P., \& Muñoz, R. (2010). A comparative evaluation of microalgae for the degradation of piggery wastewater under photosynthetic oxygenation. Bioresource Technology, 101, 5150-518. 
González, L., Cañizares, R., \& Baena, S. (1997). Efficiency of ammonia and phosphorus removal from a Colombian agroindustrial wastewater by the microalgae Chlorella vulgaris and Scenedesmus dimorphus. Bioresource Technology, 60, 259-262.

González-Garcinuño, A., Tabernero, A., Sánchez-Alvarez, J., del Valle, E., \& Galán, M. (2014). Effect of nitrogen source on growth and lipid accumulation in Scenedesmus abundans and Chlorella ellipsoidea. Bioresource Technology, 173, 334-341.

Herrero, A., Muro-Pastor, A., \& Flores, E. (2001). Nitrogen control in cyanobacteria. Journal of Bacteriology, $183,411-425$.

Hidalgo, H. (2012). Los recursos hídricos en Costa Rica, un enfoque estratégico. In B. Jiménez \& J. Galizia (Eds.). Diagnóstico del agua en las Américas (pp. 227-243). México: Foro Consultivo Científico y Tecnológico, AC.

Kong, Q., Li, L., Martínez, B., \& Ruan, R. (2010). Culture of microalgae Chlamydomonas reinhardtii in wastewater for biomass feedstock production. Applied Biochemistry and Biotechnology, 160, 9-18.

Lynch, F., Santana-Sanchez, A., Jamsa, M, Sivonen, K., Aro, E., \& Allahverdiyeva, Y. (2015). Screening native isolates of cyanobacteria and green alga for integrated wastewater treatment, biomass accumulation and neutral lipid production. Algal Research, $11,411-420$.

Martínez, M., Sánchez, S., Jiménez, J., Yousfi, F., \& Muñoz, L. (2000). Nitrogen and phosphorus removal from urban waste water by the microalga Scenedesmus obliquus. Bioresource Technology, 73, 263-272.

Muro-Pastor, I, Reyes, J., \& Florencio, F. (2005). Ammonium assimilation in cyanobacteria. Photosynthesis Research, 83, 135-150.

Nurdogan, Y., \& Oswald, W. (1995). Enhanced nutrient removal in high-rate ponds. Water Science and Technology, 31, 12, 33-43.

Olguín, E., Galicia, S., Mercado, G., \& Pérez, T. (2003). Annual productivity of Spirulina (Arthrospira) and nutrient removal in a pig wastewater recycling process under tropical conditions. Journal of Applied Phycology, 15, 249-257.

Oswald, W. (1989). The role of microalgae in liquid waste treatment and reclamation. In C. Lembi \& J. Waaland (Eds.). Algae and human affairs (pp. 255-281). Cambridge, UK: Cambridge University Press.
Park, J., Jin., H., LIm, B., Park, K., \& Lee, K. (2010). Ammonia removal from anaerobic digestion effluent of livestock waste using green alga Scenedesmus sp. Bioresource Technology, 101, 8649-8657.

Raven, J., \& Giordano, M. (2016). Combined nitrogen. In M. A.Borowitzka, J. Beardall \& J. Raven (Eds.). The Physiology of Microalgae (pp. 143-154). Switzerland: Springer.

Rippka, R. (1988). Isolation and purification of cyanobacteria. Methods in Enzymology, 167, 3-28.

Seale, D., Boraas, M., \& Warren, G. (1987). Effects of sodium and phosphate on growth of Cyanobacteria. Water Research, 21 625-631.

Shapiro, J. (1990). Current beliefs regarding dominance by blue-greens: The case for the importance of $\mathrm{CO}_{2}$ and pH. Verein. Limnology, 24, 38-54.

Silva-Benavides, A., \& Torzillo, G. (2012). Nitrogen and Phosphorus removal through laboratory batch cultures of microalga Chlorella Vulgaris and cyanobacterium Planktothrix isothrix grown as monoalgal and as co-cultures. Journal of Applied Phycology, 24, 267-276.

Subramanian, M. V., Sumathi, P., \& Sivasubramanian, V. (2009). Studies on kinetics of phosphate uptake by blue-green algae. Journal of Algal Biomass Utilization, 1, 41-60.

Tam, N., \& Wong, Y. (1996). Effect of ammonia concentrations on growth of Chlorella vulgaris and nitrogen removal from media. Bioresource Technology, 57, 45-50.

Visser, P., Ibelings, B., Van Der Veer, B., Koedood, J., \& Mur, R. (1996). Artificial mixing prevents nuisance blooms of the cyanobacterium Microcystis in Lake Nieuwe Meer, the Netherlands. Freshwater Biology, $36,2,435-450$.

Voltolina, D., Cordero, B., Nieves, M., \& Soto, L. (1999). Growth of Scenedesmus sp. in artificial wastewater. Bioresource Technology, 68, 265-268.

Voltolina, D., Gomez-Villa, H., \& Correa, G. (2005). Nitrogen removal and recycling by Scenedesmus obliquus in semicontinuous cultures using artificial wastewater and a simulated light and temperature cycle. Bioresource Technology, 96, 359-362.

Von Ruckert, G., \& Giani, A. (2004). Effect of nitrate and ammonium on the growth and protein concentration of Microcystis viridis Lemmermann (Cyanobacteria). Brazilian Journal of Botany, 27, 2, 325-331. 